- the promotion of the Programme in all appropriate jurisdictions and media.

In particular, the Interim Steering Committee is involved in the preparations for a formal International Symposium, scheduled for the Fall of 1988, and hosted by UNU in Tokyo, which will establish the Programme's main phase of operations.

\section{Current Activities}

Following the Toronto meeting, a Report of that meeting is being circulated where appropriate; and an extended Prospectus outlining the aims, objectives, administration, and provisional schedule, of the Human Response to Global Change Programme, has also been prepared for circulation (available on request from the undersigned).

In addition, a number of initial Working Groups are in the process of creation by IFIAS, in order to facilitate the development of 'leading themes' for the Programme. These Working Groups-some of which are required to undertake their activities preparatory to the full-scale adoption of the Human Response to Global Change Programme- include: a Working Group on Data Management (to liaise with the current initiative of the International Geographical Union on Global Data-Base Managment); a Working Group on the Analysis of Complex Systems; a Working Group on the 'Needs of the Most Vulnerable'; a Working Group on 'Global Risk Assessment'; and a Working Group on 'Global Environmental History'. These Groups are now being formed, and will probably be involved in the formulation of planning-documents and position-papers for the near future.

At the same time, funding is being sought for these and other activities through appropriate government, nongovernment, and private, sponsors. Further information on this most interesting new global initiative can be obtained in the first instance from the undersigned.

Peter Timmerman, Research Associate

International Federation of Institutes for Advanced Study 39 Spadina Road

Toronto

Ontario MSS 1 A4

Canada.

\title{
Proposal to Establish an International Fund for Research on the Prevention or Mitigation of Major Accidents
}

\section{Background}

Major accidents such as those at Flixborough, Seveso, Mexico City, Bhopal, Chernobyl, and the recent Rhine spill, have resulted in direct and indirect international repercussions, and in financial and economic impacts extending far beyond the immediate environment that was impacted by the disaster. As we have already seen, such accidents are just as likely to occur in industrialized as in newly industrializing countries. Moreover, in the future, the possibility of accidents greatly exceeding the international impact of those listed above have been predicted by experts working in the field.

During the past fifteen years we have come to recognize that those large-scale disasters are not due to 'acts of God', as some types of natural disasters are considered. Rather, they are the result of a series of multiple human and equipment failures over a period of time-resulting in a failurechain (sometimes exceeding 15 identifiable failures), which could have been prevented if the chain had been blocked or broken at some stage during its propagation. It is now recognized that all major accidents are preventable, but the question is: How can we identify a high-risk system a priori and implement prevention measures to block a failurechain leading to a major accident?

\section{Proposed Research}

Three levels of failure have been identified in all failurechains leading to a major accident, namely: equipment failures, human operator failures, and management-organizational system failures. Major accident investigations and the subsequent follow-up research have focused almost entirely on equipment and human operator failures, only minimal research having been carried out to date on management-organizational failures. Many equipment failures can be traced to human causes due to design, construction and/or maintenance, and testing failures. Moreover, recent studies have shown that, in most organizational systems, $80-85 \%$ of the failures are in the management and organizational elements of the system, while only $15-20 \%$ are due to so-called 'human error'.

With this new understanding we now recognize that much of the previous work in major accident investigation and prevention has been directed at only about $20 \%$ of the problem. Research work in equipment and human operator failures will continue to play a vital role in major accident prevention, but a new major research thrust is required in the area of management and organizational system failures.

This new approach to major accident prevention will be applicable to organizations in the industrial, nuclear, and hydro-energy, sectors; the defense and aerospace industries; to sea, air, road, and rail, transportation; and to any international, governmental, or private, organization seeking to prevent system failures and improve management-organizational performance. Consideration of the management-organizational system failures is not included in current risk assessment methodologies that are being applied by regulatory authorities and industrial organizations.

\section{World Bank Role in Major Accident Prevention}

Since 1984, the Bank's Office of Environmental and Scientific Affairs has played a leading international role in the application of current knowledge, the development of improved methodologies and techniques, and the provision of guidelines, manuals, and computer techniques, for major accident prevention, which have been well received in both the developed and still-developing countries. The Bank is currently co-sponsoring research, with assistance from the Danish Consultants Fund, on management and organizational factors for incorporation into a prototype Integrated Safety Audit System for Major Hazard Plants. However, this work needs to be substantially expanded in its scope and international perspective.

An outline of such a greatly-expanded research programme, designed to identify the critical managementorganizational factors in major accident prevention, is currently being developed with the assistance of international experts.

\section{Purpose and Organization of an International Fund}

The World Bank has served as an executing agency on a number of large international research efforts involving both developed and still-developing countries. The international scope of this project, and its urgency, require a similar coordinated and concentrated effort. An international expert committee would be selected to develop the research programme, ensure quality-control, and effect wide dissemination of the results. A donors' group would also be formed to provide oversight and financial support. A very small research management, coordinating, and implementing, team would operate out of the Bank. 
It is anticipated that initial funding would be for a threeyears' programme with the possibility of future extensions, if this should prove necessary. During that time, workshops would be held in various locations world-wide, to broaden the perspective of the research and encourage other independent research in the field. The proceedings of the workshops would be published and widely circulated.

Co-sponsors and research co-workers are being approached in a broad cross-section of countries and from both the private and public sectors. Those desirous of receiving additional information on this new initiative in major accident prevention are encouraged to write to: $\mathrm{Dr}$ Roger Batstone, The World Bank, Washington, DC 20433 , USA.
JAMES A. LeE, Director
Office of Environmental and Scientific Affairs
The World Bank
$1818 \mathrm{H}$ Street, $\mathrm{NW}$
Washington
DC 20433, USA

\section{Proposed Greek Law Could Kill Remaining Forests and Reduce Wetlands}

The Greek Government should withdraw a bill, now being debated in Parliament, which could drastically damage the country's already-endangered forests - according to conservation officials at WWF International, who feel that it 'could be the finishing stroke for much of the Greek forests', and claim that 'None of the economic, ecological, or social, problems were faced before the law was drafted.'

The bill, introduced by the Ministry of Agriculture, would free $61 \%$ of Greece's remaining woodlands for grazing. Woodlands freed for grazing are not reafforested in Greece. Indeed already some three-quarters of the forests of Greece have disappeared during this century, while the remainder have suffered seriously from mismanagement during recent years, according to Greek conservationists.

The same law would free drained marsh and arid lands for agricultural use. Ill-conceived drainage has already greatly reduced Greek wetlands, including those protected by the international Ramsar Convention. It is moreover to be feared that, in addition to the loss of soil, water, and

wildlife, which could follow if the law is passed, rehabilitation of threatened wetlands could be hampered, and further illegal drainage encouraged, if the law is allowed to go ahead.

Illegal and authorized encroachment for grazing, agriculture, and building, excessive woodcutting, and fire, are steadily reducing what is left of Greece's southern and central forests. Insufficient reafforestation efforts do not compensate for losses by fire, while wildlife is dwindling and erosion spreading. Yet in northern Greece, the few remaining forests are still among the least disturbed in Europe, and contain a diversity of plant and animal life that is unequalled on the rest of the continent, including as it does populations of large mammals such as bear, wolf, and lynx.

Peter Kramer, Director of Conservation $W W F$ International Avenue du Mont-Blanc 1196 Gland, Switzerland.

\section{The Federation of Ontario Naturalists, Canada}

In 1931, a group of naturalists in the Province of Ontario, Canada, formed a conservation organization named the Federation of Ontario Naturalists (FON). The primary purpose of this non-profit organization, according to one of the founding members, was 'to provide the means whereby naturalists throughout the Province might be able, collectively, to formulate policies and provide the machinery for taking whatever action is deemed necessary in support of such policies.' From the original seven clubs with a total of only 28 members in 1931, the FON has grown to an organization representing 69 member clubs and approximately 20,000 individuals, and employing 15 permanent staff and numerous volunteers. The original purpose-of providing a provincial voice for naturalists on environmental issues-remains as one of the Federation's objectives, in addition to which there is now a second objective of promoting the understanding and appreciation of Nature through public education.

Those objectives are met through a wide variety of activities which are undertaken by FON and its members. Perhaps the most visible and colourful FON activity is the quarterly magazine, Seasons. Feature articles analyse current conservation issues and introduce readers to the Province's flora, fauna, and natural areas. Regular departments report on environmental news, bird migration, volunteer projects, and events for naturalists.

Public education is also attained through the activities of the Education Program. Comprehensive kits on current environmental issues - such as acid deposition, wetland conservation, endangered wildlife, and hazardous wasteare available for different age-groups, and a recent endeavour of the programme has been the production of education videos about hazardous-waste management and acid deposition. In addition, the Education Program runs a summer camp for young naturalists.

Wetland conservation has been a specific focus for public education. Through a generous grant from the Donner Canadian Foundation, fifteen volunteer wetlands awareness groups have been organized across the greatly-populated, southern portion of the Province. These groups raise local awareness of wetlands through public seminars, shopping-mall displays, school events, and in meetings with local government officials. FON staff work at the provincial level, keeping track of wetlands legislation and casestudies, and initiating contact with agricultural associations and with other conservation organizations.

The FON is also involved in active supervision and management of natural areas in Ontario. Through gifts and purchases, the Federation has developed the largest private Nature Reserve system in the Province. These Nature reserves protect, in perpetuity, a wide spectrum of botanical and faunal habitats for Nature appreciation and education.

Providing a voice for the viewpoint of naturalists and conservationists is the mandate of the Environment Program. The program staff make submissions on provincial resource-management issues, review and comment on park management plans and new environmental legislation, and provide advice to individuals and groups taking on local environmental campaigns. The staff becomes actively involved in issues that have Province-wide ramifications, such as participation in the environmental assessment process on forestry practices in Ontario, and the campaign to establish a National Park on the Bruce Peninsula.*

Other activities of FON include support for the production of an atlas of the breeding birds of Ontario, based on five field-seasons of work by some 1,600 volunteers, the

\footnotetext{
* Successful as of 20 July 1987.-Ed.
} 